\title{
THE TRANSFORMATIVE POTENTIAL OF THE CONSTITUTIONAL ENVIRONMENTAL RIGHT OVERLOOKED IN GROOTBOOM'
}

\author{
Oliver Njuh Fuo \\ LLB LLM \\ Writing Consultant, Writing Laboratory \\ Faculty of Law, North-West University \\ Potchefstroom
}

\begin{abstract}
Summary
It is axiomatic that Grootboom (Government of the Republic of South Africa $v$ Grootboom 2001 (1) SA 46 (CC) hereinafter "Grootboom") remains the hallmark of the Constitutional Court's success in terms of its transformative socio-economic rights jurisprudence. In this regard, De Vos has argued that lawyers and legal academics who wish to pursue the transformative possibilities of the Bill of Rights may find much to assist them in the Grootboom case. One of the reasons for De Vos's recommendation is that the Court acknowledged the transformative nature of the Constitution in this Case and strongly asserted the interrelated, interdependent and mutually reinforcing nature of the rights in the Bill of Rights in achieving the transformative objectives of the Constitution. The purpose of this article is to reflect on the court's transformative jurisprudence in Grootboom and to argue that, although the court strongly asserted the interrelated and interdependent nature of the variety of rights in Bill of Rights in fostering the transformative vision of the Constitution, it failed to highlight the centrality of the section 24 environmental right in fostering that vision. This article argues that the realization of elements of the section 24 environmental right are indispensible to the realization of rights that are generally perceived as having transformative potentials - rights entrenched in sections 26(1) and $27(1)$ of the Constitution. Drawing from a variety of sources, this article demonstrates the intersection between these rights and argues that the fulfilment of the section 24 environmental right can also contribute to the transformative vision of the Constitution.
\end{abstract}

INTRODUCTION

The concept of "transformative constitutionalism" was introduced into South Africa's constitutional jurisprudence over a decade ago by Klare. ${ }^{2}$ Following this introduction, academic literature on the subject has steadily grown.

This is a revised paper that was presented at the Environmental Law Association Annual Conference of September 2011.

2 Klare "Legal Culture and Transformative Constitutionalism" 199814 SAJHR 146150.

3 Justice Langa "Transformative Constitutionalism" 2006 17(3) Stell LR 351-360; Albertyn and Goldblatt "Facing the Challenge of Transformation: Difficulties in the Development of an 
Despite consensus that the Constitution is transformative, "there is no single stable understanding" of the concept of transformative constitutionalism. ${ }^{4}$ In addition, there is diversity of opinion on the ultimate end and to an extent, means of achieving transformative constitutionalism. ${ }^{5}$ Generally, scholars on this subject are cautious in postulating a prescriptive understanding of transformative constitutionalism and it is difficult and at times impossible to formulate an understanding of this notion without running into debates. ${ }^{6}$ The intention of this section is not to focus on every disagreement that has arisen from the rich body of literature on this subject but rather to provide an overview of transformative constitutionalism to the extent that it captures the socio-economic vision of post-apartheid South Africa. ${ }^{7}$ In this context, transformative constitutionalism provides a useful device that can be used to understand the objectives and vision of the new South Africa as captured in the Constitution.

It is against the above background that this article reflects on the court's transformative jurisprudence in Grootboom. ${ }^{8}$ It argues that, although the court strongly asserted the interrelated and interdependent nature of the variety of rights in Bill of Rights in fostering the transformative vision of the Constitution, it failed to highlight the fundamental nature of the section 24 environmental right in fostering that vision. It is noted that, although the section 24 environmental right was not a fact in issue in Grootboom, it was a golden opportunity for the court to acknowledge that the enjoyment of the right to housing, health care, food, water and to an extent, social security, are dependent on the realization of the section 24 environmental right. In order to achieve the above objective, this author explains and adopts a shared understanding of transformative constitutionalism; highlights rights that are generally perceived as having a transformative potential; demonstrates the interrelated and interdependent nature of rights that are

Indigenous Jurisprudence of Equality" 199814 SAJHR 248-276; Roux "Transformative Constitutionalism and the Best Interpretation of the South African Constitution: Distinction Without a Difference?" 2009 20(2) Stell LR 258-285; Stewart "Adjudicating Socio-economic Rights Under a Transformative Constitution" 2009 28(3) Penn State International LR 487512; Liebenberg "Needs, Rights and Transformation: Adjudicating Social Rights" 2006 17(1) Stell LR 5-36; Pieterse "What Do We Mean When We Talk About Transformative Constitutionalism?" 200520 SAPR/PL 155-165; De Vos "Grootboom, the Right of Access to Housing and Substantive Equality as Contextual Fairness" 200117 SAJHR 258; Botha "Metaphoric Reasoning and Transformative Constitutionalism (Part 1)" 20024 TSAR 612627; Van Marle "Transformative Constitutionalism As/And Critique" 2009 20(2) Stell LR 286301; Sibanda "Not Purpose-made! Transformative Constitutionalism, Post-independence Constitutionalism and the Struggle to Eradicate Poverty" 2011 22(3) Stell LR 482-500; Rosa "Transformative Constitutionalism in a Democratic Development State" 2011 22(3) Stell LR 542-565.

Justice Langa 2006 17(3) Stell LR 351; and Pieterse 200520 SAPR/PL 156.

5 Albertyn and Goldblatt 199814 SAJHR 248-249; and Roux 2009 20(2) Stell LR 258-285.

6 Justice Langa 2006 17(3) Stell LR 351; and see also Pieterse 200520 SAPR/PL 155-156.

7 This area of focus is not blind to the fact that transformative constitutionalism also entails political and institutional transformation. See, eg, Albertyn and Goldblatt 199814 SAJHR 249.

8 Grootboom has been hailed for diverse reasons but especially as representing the height of the Constitutional Court's success in relation to its socio-economic rights jurisprudence. See De Vos 200117 SAJHR 276; Liebenberg "The Right to Social Assistance: The Implications of Grootboom for Policy Reform in South Africa" 200117 SAJHR 232. The popularity of this case is evidenced, eg, by the fact that there were six contributions on Grootboom in the last edition of the 201126 SA Public Law. 
generally perceived as transformative with the section 24 environmental right; and demonstrates, using Grootboom and other socio-economic rights cases that the court has not generally highlighted the transformative nature of the section 24 environmental right.

\section{TRANSFORMATIVE CONSTITUTIONALISM}

As indicated in the introduction above, there is growing academic literature on transformative constitutionalism. ${ }^{9}$ The aim of this section is not to attempt a critique of prevailing discourse on the subject but rather to explain and adopt an understanding of transformative constitutionalism that will situate the potential role of the section 24 environmental right in fostering the transformative objectives of the Constitution. However, before venturing into the diversity of opinion on what transformative constitutionalism entails, it is necessary to provide the constitutional basis for this notion.

\section{Constitutional basis}

Although the entire Constitution is transformative,${ }^{10}$ there is agreement ${ }^{11}$ that the notion of transformative constitutionalism can be situated in the Postamble to the Interim Constitution, ${ }^{12}$ now reflected in the Preamble to the Constitution. The Preamble to the Constitution unequivocally indicates that it was adopted:

"as the supreme law of the Republic so as to - heal the divisions of the past and establish a society based on democratic values, social justice and fundamental human rights; lay the foundations of a democratic and open society in which government is based on the will of the people and every citizen is equally protected by the law; improve the quality of life of all citizens and free the potential of each person".

The above extract highlights the historically self-conscious and forwarding-looking nature of the Constitution. It suggests that the establishment of a society based on social justice and democratic, accountable government is the central objective of South Africa's transformative Constitution. ${ }^{13}$

9 Stewart 2009 28(3) Penn State International LR 487-512; Justice Langa 2006 17(3) Stell LR 351-360; Pieterse 200520 SAPR/PL 155-165; De Vos 200117 SAJHR 258-276; Botha 20024 TSAR 612-627; Botha "Metaphoric Reasoning and Transformative Constitutionalism (Part 2)" 20031 TSAR 20-36; Liebenberg 2006 17(1) Stell LR 5-36; Roux 2009 20(2) Stell LR 258-285; and Van Marle 2009 20(2) Stell LR 286-301.

10 See, eg, Roederer "Transitional/Transformative Jurisprudence: Law in a Changing Society" in Roederer and Moellendorf (eds) Jurisprudence (2004) 622623.

11 Pieterse 200520 SAPR/PL 158; Justice Langa 2006 17(3) Stell LR 352; and Liebenberg 2006 17(1) Stell LR6.

12 According to the Postamble: "This Constitution provides a historic bridge between the past of a deeply divided society characterized by strife, conflict, untold suffering and injustice, and a future founded on the recognition of human rights, democracy and peaceful co-existence and development opportunities for all South Africans, irrespective of colour, race, class, belief or sex". See Postamble to the Constitution of the Republic of South Africa, Act 200 of 1993.

13 See Pieterse 200520 SAPR/PL 158-159; Klare 199814 SAJHR 153; Liebenberg 2006 17(1) Stell LR 6; and Justice Langa 2006 17(3) Stell LR 353. 


\section{Klare and transformative constitutionalism}

According to Klare, transformative constitutionalism refers to a long-term project of constitutional law-making, interpretation, and implementation, directed towards transforming political and social institutions as well as power relationships, in order to induce large-scale egalitarian social transformation. ${ }^{14}$ The processes Klare envisages in this grand project policy formulation, law-making, legal interpretation, implementation and enforcement - suggest that its fruition requires the active involvement of all spheres of government, organs of state, community-based organizations and private individuals. ${ }^{15}$ The anticipated outcome of this large-scale transformation is the establishment of "a highly egalitarian, caring, multicultural" society, underpinned by participatory democratic processes at public and private levels. ${ }^{16}$

In line with the above, Klare argues that, because the Constitution is open and committed to "large-scale, egalitarian social transformation", it is essentially a post-liberal constitution. ${ }^{17} \mathrm{He}$ asserts that unlike classical liberal constitutions, a reading of the values and variety of substantive and procedural rights entrenched in the Constitution indicates that it is "social, redistributive, caring, positive, at least partly horizontal, participatory, multicultural", conscious of its historical roots and transformative role and mission. ${ }^{18}$ After identifying these key features of the Constitution, the remainder of Klare's article is dedicated to developing a post-liberal method of reading and interpreting the Constitution that is "legally correct" and best suited to fostering the transformative role of the Constitution. ${ }^{19}$ In particular, he argues that persisting traditional legal culture impedes the full realization of the transformative potential of the Constitution and calls for a change of traditional/liberal legal culture that will enable judges to take into consideration extra-legal factors in the process of constitutional adjudication. $^{20}$

\section{Other definitions and descriptions of transformative constitutionalism}

According to Justice Langa, "the core idea of transformative constitutionalism" as expressed through the objectives of the Constitution (as found in the Preamble), is the constitutional goal of healing the wounds

\footnotetext{
Klare 199814 SAJHR 150.

lbid.

Ibid.

Klare 199814 SAJHR 150-151 and 151-156.

8 Klare 199814 SAJHR 153-156; and see also Pieterse 200520 SAPR/PL 157-158.

19 Klare 199814 SAJHR 156-188. Klare has been criticized on his argument that a particular method of constitutional interpretation, a "post-liberal" approach, is best suited to achieving the transformative objectives of the Constitution. See Roux 2009 20(2) Stell LR 258-285. See also the caution of Van Marle in Van Marle 2009 20(2) Stell LR 286-301.

20 See Klare 199814 SAJHR 158-166. See Sibanda 2011 22(3) Stell LR 488-490. For the purpose of this article, it is immaterial to venture into details of Klare's arguments on how to best interpret the Constitution.
} 
of the past and guiding South Africans to a better future. ${ }^{21}$ According to Justice Langa, the point of focus of any concept of transformative constitutionalism must be "the provision of services to all and the levelling of the economic" environment that was fundamentally skewed by the system of apartheid. ${ }^{22}$ This speaks to an unending economic and social revolution that is directed towards eradicating socio-economic inequalities. To Justice Langa, this requires the fulfilment of socio-economic rights; ensuring greater access to education, the adoption of affirmative measures to ensure greater access to opportunities for previously disadvantaged groups ${ }^{23}$ and creating conducive space for robust dialogue towards a better future.

To Pieterse, transformative constitutionalism captures three prominent features of the Constitution: the commitment to achieve social justice and substantive equality; the extension of human-rights norms into private relationships; and the requirement that any exercise of public power must be justified in accordance with the Constitution. ${ }^{25}$ Pieterse does not "pretend that this conception is a novel one" or that it is "the only tenable one, or that it is necessarily correct" but indicates that although he concurs with other characteristics of transformative constitutionalism, his areas of emphasis may differ from other scholarly definitions of the subject. ${ }^{26}$

A more holistic and somewhat radical view on transformation is provided by Albertyn and Goldblatt who argue that:

"We understand transformation to require a complete reconstruction of the state and society, including redistribution of power and resources along egalitarian lines. The challenge of achieving equality within this transformation project involves the eradication of systemic forms of domination and material disadvantages based on race, gender, class and other grounds of inequality. It also entails the development of opportunities which allow people to realize their full potential within positive social relations."

The above extract puts emphasis on the need to transform post-apartheid social and political institutions fundamentally in order to facilitate the establishment of an egalitarian society.

However, Van Marle cautions against any utopic conception of transformative constitutionalism which does not capture the aspirations of the Constitution as an ideal image while acknowledging current realities (such as structural challenges) which may impede its full realization. ${ }^{28}$ This type of acknowledgement may have influenced suggestions that transformative constitutionalism represents an unending process of societal transformation, which is historically self-conscious but forward-looking. ${ }^{29}$ It is

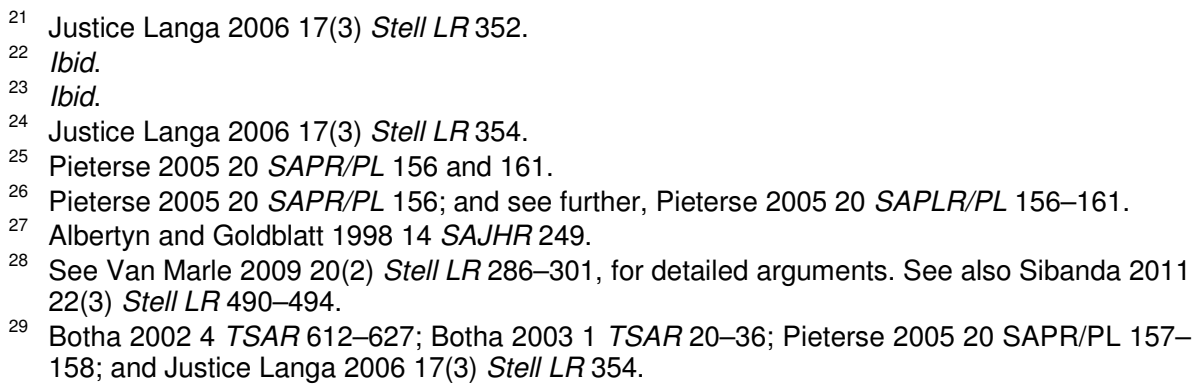


along this line of reasoning that Botha has argued that, to link transformative constitutionalism with the metaphor of a bridge is misleading as this presupposes that, like a bridge, the transformative vision of the Constitution has an endpoint, and that once that point is crossed, transformation will come to an end. ${ }^{30}$

\section{Adopted approach to transformative con- stitutionalism}

Since any attempt to formulate what constitutes transformative constitutionalism is fraught with difficulties and contestations, ${ }^{31}$ Pieterse has argued that one must reflect on the meaning and implications of any meaning attached to this notion in any given context. ${ }^{32}$ In this context, transformative constitutionalism represents the socio-economic and political vision of post-apartheid South Africa to eradicate extreme poverty and inequalities in access to basic services as well as to establish a democratic system of government that is inclusive, caring, participatory, representative and accountable. It captures the constitutional commitment to establish and maintain a society based on social justice by eradicating poverty and inequalities in access to social services. This requires the fulfilment of especially socio-economic rights and the sustained operation of a democratic system of government that is inclusive, participatory and accountable. Transformative constitutionalism therefore represents an ideal prototype of post-apartheid South African society as envisaged by its founding constitutional fathers. Although transformative constitutionalism remains an ideal, the Constitution commits the state, constitutive of public and private entities, to work towards it realization, to the fullest extent possible. This view on transformative constitutionalism draws largely from those of Langa, Pieterse and Klare discussed above. ${ }^{33}$ This article specifically focuses on that aspect of transformative constitutionalism that is essentially concerned with eradicating poverty and inequalities in access to social services.

\section{CONSTITUTIONAL PROVISIONS SUPPORTING TRANSFORMATIVE CONSTITUTIONALISM}

While the values in the Constitution represent the envisaged new South African society, the variety of rights represents a mechanism through which the envisaged society can be established. ${ }^{34}$ The Constitution adopts a holistic human-rights orientation by according special protection to all variations of fundamental rights in the Bill of Rights. It makes no reference to the classical division of human rights into different generations or into civil

\footnotetext{
30 Botha 20024 TSAR 612-627; Botha 20031 TSAR 20-36; and see Pieterse 200520 SAPR/PL 158.

31 Justice Langa 2006 17(3) Stell LR 351.

32 Pieterse 200520 SAPR/PL 155-165.

33 See ss 22 and 23 above.

34 Albertyn and Goldblatt 199814 SAJHR 249.
} 
and political rights as opposed to economic, social and cultural rights. As a result of this, all rights in the Constitution have the same status in that they are all justiciable. ${ }^{35}$ In fact, in Grootboom, the court asserted that the rights in the Bill of Rights are all interrelated, interdependent and mutually reinforcing. ${ }^{36}$ In this regard, Justice Moseneke has expressed the axiomatic view that fundamental rights cannot be meaningfully enjoyed unaccompanied by the substantive realization of socio-economic rights. ${ }^{37}$ It is against this background that certain provisions of the Constitution read solely or jointly, are consistent with the transformative vision expressed in the Constitution's Preamble. ${ }^{38}$ While accepting the view that almost all rights in the Bill of Rights support the transformative vision of the Constitution, ${ }^{39}$ this section highlights socio-economic rights that are generally considered to have the potential to promote the achievement of transformative constitutionalism.

The variety of rights generally perceived to have a transformative potential include those entrenched in sections $25^{40} 26^{41}$ and $27^{42}$ of the Constitution. ${ }^{43}$ Commenting about their transformative potential, Pieterse notes that:

"Their entrenchment alongside civil and political rights not only underscores the constitutional commitment to address the economic and social legacies of apartheid ... but also acknowledges and explicitly targets the social

35 Pieterse "Coming to Terms with Judicial Enforcement of Socio-Economic Rights" 2004 SAJHR 388-417; Moseneke "The Fourth Bram Fischer Memorial Lecture" 200218 SAJHR 317 and 318; Olivier "Constitutional Framework" in Olivier (ed) Introduction to Social Security (2004) 123-125. The court laid to rest this debate in the Grootboom case par 20. This debate was long settled in South Africa. See Certification of the Constitution of South Africa, 1996 par 76-77; and The Grootboom case par 20 and 30.

${ }^{36}$ See the Grootboom case par 83; and De Vos 200117 SAJHR 264.

37 Moseneke 200218 SAJHR 318.

38 Justice Langa 2006 17(3) Stell LR 352-353; and Pieterse 200520 SAPR/PL 161.

39 De Vos 200117 SAJHR 264

40 S 25 of the Constitution entrenches the right to property. Of particular importance is s $25(5)$ which provides that: "The state must take reasonable legislative and other measures, within its available resources, to foster conditions which enable citizens to gain access to land on an equitable basis."

${ }^{41}$ S 26 provides that: "(1) Everyone has the right to have access to adequate housing. (2) The state must take reasonable legislative and other measures, within its available resources, to achieve the progressive realisation of this right.(3) No one may be evicted from their home, or have their home demolished, without an order of court made after considering all the relevant circumstances. No legislation may permit arbitrary evictions." Although the Court in Grootboom decided on the nature/scope of the right of access to adequate housing (see, eg, par 34-35 and 37), it has persistently rejected calls to give normative content to the right of access to adequate housing. See Grootboom par 32-33; and Nokotyana v Ekurhuleni Metropolitan Municipality [2009] ZACC 33 par 48.

42 S 27 provides that: "(1) Everyone has the right to have access to- (a) health-care services, including reproductive health care; (b) sufficient food and water; and (c) social security, including if they are unable to support themselves and their dependents, appropriate social assistance. (2) The state must take reasonable legislative and other measures, within its available resources, to achieve the progressive realization of each of these rights. (3) No one may be refused emergency medical treatment."

43 See Pieterse 200520 SAPR/PL 162-163; and Klare 199814 SAJHR 153-155. 
component of individual vulnerability, by requiring that the State ameliorate

the consequences of such vulnerability in a variety of sectors."

However, the textual wording of these rights, especially sections 26 and 27 , indicates clearly that these are long-term commitments which cannot be realized immediately. ${ }^{45}$ The only immediate commitment seems to be the negative obligation not to impede current enjoyment of these rights. ${ }^{46}$

\section{INTERSECTIONS BETWEEN SECTION 24 ENVIRONMENTAL RIGHT AND OTHER TRANS- FORMATIVE RIGHTS}

This section begins by briefly highlighting the centrality of environmental considerations in basic needs satisfaction and poverty alleviation with a focus on inter alia UN Agenda $21 .{ }^{47}$ This is informed by a conception of an inherently anthropocentric orientation of environmental rights. ${ }^{48}$ The intention is to develop sufficient background information to support the view that fulfilment of South Africa's constitutional environmental right can contribute towards the realization of the rights entrenched especially in section 26(1) and 27(1) of the Constitution. This background is informed by the argument that the realization of socio-economic rights are environmental resources dependent. ${ }^{49}$ Based on the interpretation of the constitutional environmental right, this section also illustrates the interrelated, interdependent and mutually reinforcing nature of these rights and the fact that fulfilment of South Africa's environmental right can therefore contribute towards the achievement of the transformative goals of the Constitution. ${ }^{50}$

\section{The environment as the basis for needs satisfaction}

Over the past three decades, there has been increased awareness of the negative impact of human activities on the environment as well as lifethreatening environmental trends. ${ }^{51}$ Increased deforestation and desertification have contributed to inter alia water scarcity and food insecurity, which threaten the lives of many species on the planet, including

44 See Pieterse 200520 SAPR/PL 163. See also Brand "Introduction to Socio-economic Rights in the South African Constitution" in Brand and Heyns (eds) Socio-economic Rights in South Africa (2005) 2

45 See The Grootboom case par 45

46 De Vos 200117 SAJHR 262

47 For a critical discussion of this topic within the context of South Africa, see Du Plessis "South Africa's Environmental Right Generously Interpreted: A Focus on the Role of Poverty" 2011 27 SAJHR 279-307.

48 Tomasevski "Environmental Rights" in Eide, Krause and Rosas (eds) Economic, Social and Cultural Rights: A Textbook (1995) 257.

49 See, eg, Tomasevski in Eide et al (eds) Economic, Social and Cultural Rights: A Textbook 257-261.

50 This idea has already been forcefully argued by Du Plessis. See Du Plessis 201127 SAJHR 279-307.

51 Feris and Tladi "Environmental Rights" in Brand and Heyns (eds) Socio-Economic Rights in South Africa (2005) 249. 
human beings. ${ }^{52}$ All over the world, the heavy reliance and burning of fossil fuels releases into the atmosphere carbon dioxide which remains a leading cause of global warming. This greenhouse effect has increased global temperatures with often negative impacts on food production, rise in sea levels and the flooding of coastal towns and cities. ${ }^{53}$ Frequent floods are often accompanied by the destruction of infrastructure and agricultural farms, with often catastrophic effects on the economy and general standard of living. ${ }^{54}$ In addition, industrial gases contribute to the depletion of the ozone layer with a consequent increase in animal and human cancer and a disruption of the oceans' food chain. ${ }^{55}$ Moreover, toxic substances discharged from industrial and agricultural production affect food quality and underground water tables. ${ }^{56}$ It is projected that Africa is most likely to be the hardest hit by these life-threatening environmental trends. ${ }^{57}$ Increased deforestation, desertification, droughts, famine, floods, population growth and pollution of water resources are expected to increase poverty, population displacements and increased conflict over limited resources. South Africa is not an exception. ${ }^{59}$

The importance of environmental management in meeting basic human needs, fighting poverty, hunger, ill health and contributing towards general socio-economic development came to the forefront at the international, regional and national levels, following developments during and after the United Nations Conference on Environment and Development (UNCED). ${ }^{60}$ This awareness is adequately captured in the opening paragraph of UN Agenda 21 to the effect that:

"Humanity stands at a defining moment in history. We are confronted with a perpetration of disparities between and within nations, a worsening of poverty, hunger, ill health and illiteracy, and the continuous deterioration of the ecosystems on which we depend for our well-being. However, integration of environment and development concerns and greater attention to them will lead to the fulfilment of basic needs, improved living standards for all, better protected and managed ecosystems and a safer, more prosperous future."

52 WCED "Report of the World Commission on Environment and Development (WCED): Our Common Future" (1987) par 7.

53 Ibid.

54 Ibid.

55 Ibid.

56 Ibid.

57 See Centre for International Governance Innovation "Climate Change in Africa: Adaptation, Mitigation and Governance Challenges" (2009) 8-40; and Patz, Campbell-Lendrum, Holloway and Foley "Impact of Regional Climate Change on Human Health" 2005 Nature 310-317; and Morton "The Impact of Climate Change on Smallholder and Subsistence Agriculture" 2007 Proc Natl Acad Sci 19680-19685.

58 lbid.

59 Kotze "Phiri, the Plight of the Poor and the Perils of Climate Change: Time to Rethink Environmental and Socio-economic Rights in South Africa?" 2010 Journal of Human Rights and the Environment 135-160; Mazibuko v City of Johannesburg 20103 BCLR 239 (CC) par 2-3; and Du Plessis 2011 SAJHR 289.

60 Held in Rio de Janeiro, Brazil, 3-14 June1992.

61 See Agenda 21 of the UN Conference on Environment and Development (1992), par 1.1 of Chapter 1: Preamble. 
In the same vein, Agenda 21 stresses the adverse effects of poor environmental management on access to basic needs such as drinkingwater supply, worsening levels of poverty, diseases, ill health and an alarming rise of death rates in especially developing countries. ${ }^{62}$

Generally, there have been several legal responses to address the destructive effects of human activities on the environment in order to promote an environment that is conducive to human health and well-being. ${ }^{63}$ A legal response that has witnessed considerable acceptance in recent years is the increased constitutional protection of environmental rights and express commitment to the principle or underlying ideals of sustainable development. $^{64}$

\section{Section 24 environmental rights and its intersection with sections 26 and 27}

In the South African context, the notion of sustainable development is phrased within the section 24 constitutional environmental rights. Section 24 of the Constitution provides that:

"Everyone has the right - (a) to an environment that is not harmful to their health or well being; and (b) to have the environment protected for the benefit of present and future generations, through reasonable legislative and other measures that (i) prevent pollution and ecological degradation; (ii) promote conservation; and (iii) secure ecologically sustainable development and use of natural resources while promoting justifiable economic and social development."

The National Framework for Sustainable Development in South Africa indicates that sustainable development is captured in section 24(b) of the Constitution. ${ }^{65}$ This move by South Africa brings the Constitution in line with global and regional trends towards environmental protection. ${ }^{66}$ The increasing move towards sustainable development is based on the realization that because the environment "is the basis of all economic activity and of life itself it is only right that the quality and integrity of the environment be maintained' for current and future generations".

62 See par 18.47 of UN Agenda 21 - UN Conference on Environment and Development (1992). See also Kotze "Access to Water in South Africa: Constitutional Perspectives from a Developing Country?" 20091 Finnish Environmental LR 70 71-75.

63 Kotze 2010 Journal of Human Rights and the Environment 136.

64 For an analysis of the extent to which some African countries have entrenched environmental protection and the principle of sustainable development in their constitutions, see generally Faure and Du Plessis The Balancing of Interests in Environmental Law in Africa (2011); and Kotze 2010 Journal of Human Rights and the Environment 136.

65 DEA People-Planet-Prosperity: A National Framework for Sustainable Development (2008) 14.

66 At the African regional level for example, the African Charter on Human and Peoples' Rights, adopted on June 271981 and entered into force on 21 October 1986, protects in article 24 the right of all people "to a general satisfactory environment favourable to their development".

67 See Elliot An Introduction to Sustainable Development 3ed (2006) 14. 
Although sustainable development has different and most often conflicting definitions, ${ }^{68}$ it is a shared view that the principle emphasizes inter alia that any pursuit of development must: integrate environmental, social and economic considerations; promote public participation in governance; address social and economic inequalities by for example meeting the basic needs of impoverished persons; promote sustainable and equitable use of natural and cultural resources; and cater for the interest of future generations. ${ }^{69}$ These areas of emphasis could also be seen as mutually reinforcing objectives of sustainable development. ${ }^{70}$ According to the World Commission on Environment and Development (WCED), the most important objectives of sustainable development are to: revive and change the quality of growth; meet essential needs for jobs, water, sanitation, energy and food; ensure a sustainable level of population growth; conserve and enhance the ecological resource base; re-orientate technology in order to promote sustainable patterns of trade and manage risk; and integrate the environment into economic decision-making.

Du Plessis argues that, although the court is yet to give content to the scope or normative meaning of the section 24 constitutional environmental right, the notions of intergenerational equity and sustainable development provide a useful start to its understanding. ${ }^{72}$ She indicates that section $24(\mathrm{~b})$ of the Constitution guarantees intergenerational environmental protection to the people of South Africa while imposing an obligation on the state to adopt and implement inter alia legislation and policies that will secure sustainable development. ${ }^{73}$ As evident from the preceding paragraph, sustainable development seeks to ensure the effective management of the environment in the process of socio-economic growth in order to inter alia redistribute resources that will ensure the eradication of socio-economic inequalities by specifically meeting the basic needs of impoverished persons such as water, sanitation, food, energy, and ensuring an improved standard of living,

68 The Brundtland Report defined sustainable development as "development which meets the needs of the present without compromising the ability of future generations to meet their own needs". See par 1 of Chapter 2.1 The Concept of Sustainable Development in "Report of the World Commission on Environment and Development (WCED): Our Common Future" (1987). South Africa's definition of sustainable development is influenced by the definition in the Brundtland Report and is now couched in section 24(b) of the Constitution. See Department of Environmental Affairs and Tourism People-Planet-Prosperity: A National Framework for Sustainable Development in South Africa (2008) 14. For other definitions, see Bossel Indicators for Sustainable Development: Theory, Method, Applications (1999) 2-3; Elliot An Introduction to Sustainable Development 7-14.

69 Urquhart and Atkinson A Pathway to Sustainability: Local Agenda 21 in South Africa (2000) 20-21; Burns and Hattingh "Locating Policy Within the Taxonomy of Sustainable Development" 2007 SAJELP 3-5; and De Visser "The Institutional Framework for Developmental Local Government: Making Good on the Promise of Development?" Colloquium on Local Government Law Potchefstroom University (Potchefstroom, October 2001) 2-3.

70 See Elliot An Introduction to Sustainable Development 11-14.

71 "Report of the World Commission on Environment and Development (WCED): Our Common Future" (1987) par 27-30; and Elliot An Introduction to Sustainable Development 13.

72 See Du Plessis 2011 SAJHR 290.

73 Ibid. 
including health for everyone. ${ }^{74}$ To Du Plessis, sustainable development is mainly about eradicating poverty and inequalities in a manner that allows for the rebuilding of ecosystems and the natural resources that human beings depend on for their collective survival. ${ }^{75}$ On the other hand, intergenerational equity emphasizes the need to manage the country's natural resource base in such a way that future generations will be able to have equal access thereto. ${ }^{76}$ This seeks to ensure that prudent management of the environment continues ad infinitum as today's generation bequeaths the obligation to secure sustainable development through legislative and other measures to the next generation.

While section 24 of the Constitution guarantees the right to sustainable development and intergenerational environmental equity, it does not expressly guarantee especially impoverished persons the right to food, water, health care, social security and housing. The right of access to health care, food, water, social security and housing is expressly guaranteed in sections 26(1) and 27(1) of the Constitution subject to the availability of resources. Owing to the fact that the realization of the sections 26(1) and 27 (1) rights is entirely dependent on the availability of resources, it becomes obvious that a strong relationship exists between the meaning and right to sustainable development embedded in section 24(b) and the explicit reference to "health" and "well-being" in section 24(a) of the Constitution, respectively. This point is clearly articulated by Du Plessis when she argues that:

"Although section 24 is cast in broadly-construed terms, it protects their right to live a healthy life, to enjoy well-being and to have their own and their children's natural environment protected. Thus, s 24 indirectly relates to the basic services associated with these entitlements. However, it also refers to a broader spectrum of other basic needs in so far as it expressly refers to sustainable development ... health ..;7 and well-being ... These notions are wide open to (creative) interpretation.

Based on the phraseology of the section 24 constitutional environmental right, and in line with the views in the above extract, Du Plessis argues that in addition to sustainable development, there are three additional objectives of the constitutional environmental right: to protect the "environment", and promote human "health", and "well-being".

Firstly, because the environment in the South African context is conceived in anthropocentric terms, the section 24 environmental right seeks to ensure that the interrelationship between people and the natural environment is such that the environment is not and does not become harmful to people's health or well-being. ${ }^{79}$ This interrelationship must cater for people's dependence on the environment for resources such as drinking water, food,

74 Urquhart and Atkinson A Pathway to Sustainability: Local Agenda 21 in South Africa 20-21. Burns and Hattingh 2007 SAJELP 3-5; De Visser Colloquium on Local Government Law Potchefstroom University (Potchefstroom, October 2001) 2-3.

75 Du Plessis 2011 SAJHR 279.

76 Du Plessis 2011 SAJHR 290.

77 See Du Plessis 2011 SAJHR 291.

78 See Du Plessis 201127 SAJHR 292-297.

79 See Du Plessis 201127 SAJHR 293. 
and air to breathe..$^{80}$ In this regard, she argues that what is perceived as "environmental quality" goes beyond the conservation of natural resources and has much to do with people's health, access to water and sanitation, as well as land use. ${ }^{81}$ In addition, she argues that:

"future growth and the improvement of the quality of life depend on the quality of people's environment and their ability to live healthy lives, whilst the reduction of poverty in the country's urban and rural areas is a crucial precondition for reducing environmental problems such as soil and water pollution and other environmentally unsustainable practices".

In addition, the section 24 environmental right seeks to ensure that the natural environment is managed in such a way that enables people to live and work under conditions that will not harm their mental and physical health. ${ }^{83}$ It has been stressed that health "is a fundamental human right indispensible for the exercise of other human rights". ${ }^{84}$ The human right to health has been interpreted to include food, clothing, housing, medical care and other social services. ${ }^{85}$ Therefore, addressing conditions that affect human health negatively, which is an objective of the constitutional environmental right, has the potential to foster the realization of other socioeconomic rights. The environment is an "underlying determinant" of the right to health and other associated socio-economic rights. ${ }^{86}$ Based on this theoretical framework, it becomes practically possible to locate a right to health arising from the section 24 environmental right. However, this possibility is diminished by the court's jurisprudence relating to the principle of constitutional subsidiarity, which demonstrates that the court will not be prepared to enforce the section $27(1)$ health rights through the section 24 environmental right, for example. ${ }^{87}$ The same can also be said of the rights of access to sufficient water and food. ${ }^{88}$ The rights to water and food will be compromised if, for example, ground water pollution is not prevented or effectively managed. This possibility is clearly illustrated in the recent Carolina Cases, where acid mine drainage polluted the water resources of the Carolina community, thereby depriving residents of drinkable water. ${ }^{89}$

80 Ibid.

81 See Du Plessis 201127 SAJHR 285. Water, air and soil constitute the three environmental media. See Kotze 20091 Finnish Environmental LR 75.

82 See Du Plessis 201127 SAJHR 285

83 See Du Plessis 201127 SAJHR 293-294. See Horsten, Janse Van Rensburg, Olivier and Mpedi "Socio-economic Rights" in Govindjee and Vrancken (eds) Introduction to Human Rights Law (2009) 170.

84 See par 1 of CESCR General Comment No:14: The Right to the Highest Attainable Standard of Health (2000).

85 Ibid. For details of the normative content of the right to health, see par 8-13 of CESCR General Comment No 14

86 See par 11 of CESCR General Comment No14: The Right to the Highest Attainable Standard of Health (2000).

87 See Mazibuko $v$ City of Johannesburg supra par 73-74.

88 See Du Plessis 201127 SAJHR 294; and Kotze 2009 Finnish Environmental LR 74-75.

89 See Federation for Sustainable Environment $v$ Minister of Water Affairs, North Gauteng High Court, Republic of South Africa (Pretoria), Case No:35672/12, 10 July 2012; Federation for Sustainable Development v Minister of Water Affairs (2012) North Gauteng High Court, Pretoria, Case No: 35672/12 of 26 July 2012 as corrected in Federation for Sustainable Development v Minister of Water Affairs (2012) North Gauteng High Court, Pretoria, Case 
This point further reinforces the need to fulfil the right of access to sanitation. Without fulfilling this right, there is the danger that open defecation can result to underground-water pollution with multiple affects. ${ }^{90}$ In general, protection from increasingly life-threatening environmental trends such as global warming, unacceptable levels of carbon-dioxide emissions, industrial discharge of toxic waste, floods, deforestation and desertification, all fall within the ambit of the protection accorded South Africans by the section 24 environmental right. Ineffective legal and other responses to these lifethreatening environmental trends have the potential to affect peoples' health negatively through for example the spread of diseases. ${ }^{91}$

Furthermore, an objective of the constitutional environmental right, evident from section 24(a), is the promotion of peoples' "well-being". ${ }^{22}$ Although "well-being" is defined as "general health and happiness", Du Plessis argues that this provision obliges the state to protect peoples' "welfare", in a manner that relates to environmental interests but which does not obviously have health implications. ${ }^{94}$ The reference to "well-being" would then suggest that, in this context, section 24(a) of the Constitution seeks to protect aesthetic interests which people may hold in the environment. ${ }^{95}$ Such aesthetic interests may also embrace a sense of spiritual and psychological well-being. In this context, it has been suggested that such an entitlement does not directly embrace other socio-economic rights. ${ }^{96}$

Owing to its strong inclination to the principle of sustainable development, section 24 of the Constitution indicates that one of its objectives is to ensure the balancing of socio-economic and environmental interests in development-planning processes. These interests include human needs such as food, water, sanitation and energy, which must be satisfied in the short, medium to long term. ${ }^{97}$ For example, in terms of development planning, every municipality is required by section $9(1)$ of the Housing Act, ${ }^{98}$ as part of its integrated development planning and within national and provincial housing legislation and policy, to take reasonable and necessary steps to inter alia prevent or remove conditions not conducive to the health and safety of inhabitants within its jurisdiction. ${ }^{99}$ This is consistent, for example, with section 24(a) of the Constitution which provides the right to an

No: 35672/12 of 3 August 2012; and Federation for Sustainable Development $v$ Minister of Water Affairs (2012) North Gauteng High Court, Pretoria, Case No: 35672/12 of 15 August 2012.

90 Bilchitz "Is the Constitutional Court Wasting Away the Rights of the Poor? Nokotyana $v$ Ekurhuleni Metropolitan Municipality" 2010 127(4) SALJ 591.

91 See Centre for International Governance Innovation "Climate Change in Africa: Adaptation, Mitigation and Governance Challenges" (2009) 16-20.

92 For a critical engagement with the implications of the notion of well-being, see Du Plessis 201127 SAJHR 295-297.

93 Hornsby Oxford Advanced Learner's Dictionary 6ed (2000) 1356.

94 Du Plessis 201127 SAJHR 295.

95 Ibid.

96 Ibid.

97 See Du Plessis 201127 SAJHR 298.

98 Housing Act 107 of 1997.

99 See Nokotyana case par 28. 
environment not harmful to health and well being and the section 24(b)(i) constitutional right to have an environment protected from pollution.

Despite the importance of environmental considerations to realizing certain socio-economic rights as highlighted above, it is only recently that environmental protection has emerged as a fundamental consideration in socio-economic-rights discourse in South Africa. ${ }^{100}$ Owing to the fundamental role that effective environmental management can contribute towards poverty alleviation and in securing for all members of society a basic quality of life, like all other socio-economic rights, it has been argued that South Africa's section 24 environmental rights should be viewed as a socioeconomic right. ${ }^{101}$ Therefore, the section 24 constitutional environmental right provides entitlements that go beyond what is needed for biological survival $^{102}$ and is central to the realizing the objectives of the Constitution to improve the lives of all and attain social justice. ${ }^{103}$ This is attributed to the fact that, certain elements of the broad section 27 rights to health, access to sufficient quantity and quality of water and food, as well as the section-26 right of access to adequate housing are interdependent and reinforced by the fulfilment of elements of the section 24 environmental rights.

\section{REFLECTIONS ON THE COURT'S TRANS- FORMATIVE JURISPRUDENCE IN GROOTBOOM}

\section{Brief facts and court's decision}

Mrs Grootboom and most of the respondents lived under "lamentable conditions" in Wallacedene, an informal settlement on the edge of the Oostenberg municipal area. A quarter of the households of Wallacedene had no income at all, more than two thirds earned less than R500 per month and about half of the population were children. The residents had no water, sewage or refuse-removal services and only $5 \%$ of the shacks had electricity. The settlement was "partly waterlogged and lies dangerously close to a main thoroughfare". ${ }^{104}$ The respondents had applied for low-cost housing from the municipality and had been on the waiting list for about 7 years. Tired of waiting, and faced with the prospects of remaining in intolerable conditions indefinitely, the respondents moved out of Wallacedene and put up their shacks and shelters on vacant privately owned

\footnotetext{
${ }^{100}$ This argument has been forcefully made by Du Plessis. See Du Plessis 201127 SAJHR 279-307. See also Manda "Introducing Socio-Economic Rights" in Liebenberg and Pillay (eds) Socio-Economic Rights in South Africa: A Resource Book (2000) 9 23. Although some South African scholars have discussed the section 24 environmental right under "Socioeconomic rights", they do not offer any motivation for this right to be considered as a socioeconomic right or on the role which it can play in fostering the realisation of traditionally perceived socio-economic rights. See, eg. Horsten et al in Govindjee and Vrancken (eds) Introduction to Human Rights Law (2009) 170-171; Nichol and Winstanley "Environmental Rights" in Liebenberg and Pillay (eds) Socio-Economic Rights in South Africa: A Resource Book (2000) 131-154.

101 See Du Plessis 201127 SAJHR 279-307.

102 See Du Plessis 201127 SAJHR 282.

${ }^{103}$ Du Plessis 201127 SAJHR 281; and Bilchitz 2010 SALJ 127(4) 591603.

${ }^{104}$ See par 7 of Grootboom (author's own emphasis added).
} 
land that had been earmarked for low-cost housing, without the consent of the owner. They called their new found home "New Rust". ${ }^{105}$ The owner of "New Rust", after obtaining an eviction order, evicted the respondents from his property "prematurely and inhumanely" in the winter of 1999.

Upon eviction, the respondents could not return to their former sites at Wallacedene which had been occupied by strangers. Faced with these events, they went and sheltered on the Wallacedene sportsfield "under such temporary structures as they could muster". Worried about their intolerable conditions, the respondents launched an urgent application in the High Court to force the municipality to provide temporary accommodation in order to meet its constitutional obligations in respect of the section-26 right of access to housing. The High Court granted relief to the respondents which was appealed to the Constitutional Court by the appellants.

The court held that the nationwide housing programme falls short of obligations imposed by section 26(2) because it fails to recognize that the state must provide relief for those in desperate need. ${ }^{107}$

\section{The transformative nature of the Constitution acknowledged}

In his opening statement, Yacoob $\mathrm{J}$ confirmed the transformative objectives of the Constitution as follows:

"The people of South Africa are committed to the attainment of social justice and the improvement of the quality of life for everyone. The Preamble to our Constitution records this commitment. The Constitution declares the founding values of our society to be "[h]uman dignity, the achievement of equality and the advancement of human rights and freedom". This case grapples with the realization of these aspirations for it concerns the state's constitutional obligations in relation to housing: a constitutional issue of fundamental importance to the development of South Africa's new constitutional order."

Despite asserting the transformative nature of the Constitution, Yacoob J is quick to point out the harsh realities that millions of South Africans confront daily and the fact that the achievement of constitutional aspirations is a long-term project, which unfortunately cannot be achieved in the short term. As he put it, "[T] he case brings home the harsh reality that the Constitution's promise of dignity and equality for all remains for many a distant dream".

\footnotetext{
${ }^{105}$ See par 8 of Grootboom.

${ }^{106}$ See par 9-10 of Grootboom for details.

107 See Grootboom, par 66-69 for details.

${ }^{108}$ Par 1 of Grootboom. Footnote omitted. See also par 25 where Yacoob J quotes with approval, Chaskalson P in Soobramoney v Minister of Health, Kwa-Zulu-Natal 1997 (12) BCLR 1696.
} 


\section{Interrelated nature of rights: environmental considerations overlooked}

The court stressed the interrelated and interdependent nature of the rights in the Bill of Rights in several paragraphs, as follows:

"The key constitutional provisions in this case are section 26 and 28(1)(c) ... These rights need to be considered in the context of the cluster of socioeconomic rights entrenched in the Constitution. They entrench the right of access to land, to adequate housing and to health care, food, water and socjal security. They also protect the rights of the child and the right to education.

... All the rights in the Bill of Rights are interrelated and mutually supporting ... Affording socio-economic rights to all people therefore enables them to enjoy the other rights enshrined in Chapter 2. The realisation of these rights is also key to the ... evolution of a society in which men and women are equally able to achieve the full potential.

The right of access to adequate housing cannot be seen in isolation. There is a close relationship between it and other socio-economic rights. Socioeconomic rights must all be read together in the setting of the Constitution as a whole. The state is obliged to take positive action to meet the needs of those living in extreme conditions of poverty, homelessness or intolerable housing. Their interconnectedness needs to be taken into account in interpreting the socio-economic rights, and, in particular, in determining whether the state has met its obligations in terms of them.

But section 26 is not the only provision relevant to a decision as to whether state action at any particular level of government is reasonable and consistent with the Constitution. The proposition that rights are interrelated and are all equally important is not merely a theoretical postulate. The concept has immense human and practical sjgnificance in a society founded on human dignity, equality and freedom ...."

As is evident from the above extracts, the court did not at any moment specifically make mention to the section 24 environmental right. Even though this was not a fact in issue, the facts of the Case and the "intolerable" circumstances in which residents of Wallacedene lived raised some practical environmental considerations. For example, according to the judgment of Yacoob J, residents of Wallacedene lived "perilously close to the roads", in "shacks permanently flooded during winter rains" and the entire Wallacedene "area is partly waterlogged and lies dangerously close to a main thoroughfare". ${ }^{113}$ These descriptions suggest human habitation of a low-lying area prone to floods, noise pollution and deaths resulting from road-side accidents. Furthermore, the "waterlogged" nature of Wallacedene suggests a fertile breeding ground for vectors of diseases that pose a health risk to residents. ${ }^{114}$ These also suggest the government's failure, in this case the municipality, to fulfil its section 24 environmental obligations which entitle

${ }^{109}$ Grootboom par 19

110 Grootboom par 23.

111 Grootboom par 24

112 Soobramoney v Minister of Health, Kwa-Zulu-Natal supra par 83.

${ }^{113}$ See par 7and 59 of Grootboom.

114 This is contrary to the view of the Committee on ESCR. See par 8 of ESCR General Comment 15 of 2002. 
everyone to an environment that is not harmful to their health and well-being and to protection from pollution.

In addition to the above, the failure of the court to highlight the centrality of the section 24 environmental right in fostering the transformative objectives of the Constitution in Grootboom may be attributed to its weakness in perceiving that environmentally derived resources are needed to realize other interrelated and interdependent rights. The importance of resources in fulfilling socio-economic rights was acknowledged by the court when it quoted with approval Soobramoney to the effect that:

"What is apparent from these provisions is that the obligations imposed on the State by ss 26 and 27 in regard to housing, health care, food, water, and social security are dependent upon the resources available for such purposes, and that the corresponding rights themselves are limited by reason of lack of resources. Given this lack of resources and the significant demands on them that have already been referred to, an unqualified obligation to meet these needs would not presently be capable of being fulfilled."

Based on the above, it is argued that resources in this instance should not be limited to financial and human resources but must be interpreted broadly to include a balance of environmental resources such as surface-water resources, biological resources (including soil resources) and scenic resources ${ }^{117}$ without which the rights in sections 26(1) and 27(1) cannot be realized. It is in this regard that sustainability has been motivated as a criterion in determining the reasonableness of measures adopted to give effect to rights, such as water. ${ }^{118}$ While sustainability is the central thread that runs through environmental management, it encapsulates diverse environmental considerations which may be peculiar to a context. A house for example, will not pass the adequacy threshold that forms part of the reasonableness standard if it is constructed on a mine site that has not been rehabilitated effectively. In this regard, soil strength and quality are extremely important considerations when constructing an adequate house. In view of the above, it can be argued that the test of reasonableness set out in Grootboom did not capture environmental considerations sufficiently. ${ }^{119} \mathrm{Du}$ Plessis argues that:

"in dealing with cases involving the poor generally, the courts must also bear in mind the objectives of the constitutional environmental right. In doing so they ought to be sensitive towards and recognise, in the process of constitutional interpretation, the possible connection between sets of facts,

${ }^{115}$ For details on the nature of local government's obligation towards fulfilling the $s-24$ constitutional environmental right, see Du Plessis Fulfilment of South Africa's Constitutional Environmental Right in the Local Government Sphere (2008). See also De Wet and Du Plessis "The Meaning of Certain Substantive Obligations Distilled from International Human Rights Instruments for Constitutional Environmental Rights in South Africa" 2010 10(2) African Human Rights LJ 345-376.

116 Soobramoney $v$ Minister of Health, Kwa-Zulu-Natal supra par 11. See par 46 of Grootboom.

${ }^{117}$ For an explanation of these environmental resources, see: http://www.environment. gov.za/enviro-info/env/resource.htm (accessed 2011-09-22).

118 Stewart and Horsten "The Role of Sustainability in the Adjudication of the Right to Access to Adequate Water" 2009 SA Public Law 487-505.

${ }^{119}$ Grootboom par 39-45. 
issues relating to poverty and the nature of the protection afforded by section $24 \ldots . . .12$

In addition, it is argued that the sustainability of houses per se must also be considered as a requirement when determining the adequacy or reasonableness of an adequate house. It is argued that, although notion of sustainability appears in the Grootboom judgment, ${ }^{121}$ it appears to be tied to the implementation of the land programme adopted by the Cape Metro to meet the needs of the poor and not precisely the sustainability of the houses constructed under such a programme. ${ }^{122}$ As part of the reasonableness standard, it is argued that an adequate house must be constructed in an area free of unacceptable levels of pollution.

It should be noted that the failure of the court to contextualize and acknowledge the relevance of the section 24 constitutional environmental right in realizing rights traditionally perceived to have a transformative potential in the highly acclaimed Grootboom Case has continued in subsequent socio-economic-rights cases. For example, although the Mazibuko Case raised issues relating to the right of access to water guaranteed in section 27(1)(b) of the Constitution and "no access to basic sanitary services", the court was silent on the importance of the section 24 environmental right in that context. The court simply referred to the "need to preserve water" and "careful management of a scare resource". ${ }^{123}$ Despite the above, the Western Cape High Court held that the provision of unenclosed toilets to residents of Makhaza Informal Settlement violated inter alia, their section 24 constitutional environmental right. ${ }^{124}$ However, this orientation of the High Court must have been informed by the fact that violation of the environmental right was specifically a fact in issue. ${ }^{125}$

\section{CONCLUSION}

The purpose of this article was to reflect on the court's transformative jurisprudence in Grootboom. It argues that, although the court acknowledged the interrelated and interdependent nature of the variety of rights in Bill of Rights in promoting the transformative objectives of the Constitution, it failed to highlight the indispensable nature of the section 24 environmental rights in promoting constitutional objectives. It is noted that, although the section 24 environmental right was not a fact in issue, it was a golden opportunity for the court to acknowledge that the enjoyment of the right to housing, health care, food, water and to an extent, social security, are dependent on the realization of the section 24 environmental right. Grootboom therefore represent a missed opportunity in this regard.

\footnotetext{
${ }^{120}$ Du Plessis 201127 SAJHR 291.

${ }^{121}$ See Grootboom par 67.

122 Ibid.

${ }^{123}$ See Mazibuko $v$ City of Johannesburg supra par 3.

${ }^{124}$ See Ntombentsha Beja v Premier of Western Cape (2011) Case No: 21332/10 (Unreported). See especially par 192.

${ }^{125}$ See par 7 of Ntombentsha Beja v Premier of Western Cape supra.
} 